\title{
Preparation and Characterization of Zinc Oxide Based Photoanode for Dye-sensitized Solar Cell using Delonix Regia Natural Dye Extract
}

Leela Pradhan Joshi, Yamuna Poudel, Mim Lal Nakarmi, Pradip Raj Niraula, Shankar Prasad Shrestha

Journal of Nepal Physical Society Volume 4, Issue 1, February 2017 ISSN : 2392-473X

Editors:

Dr. Gopi Chandra Kaphle

Dr. Devendra Adhikari

Mr. Deependra Parajuli

JNPS, 4 (1), 1-6 (2017)

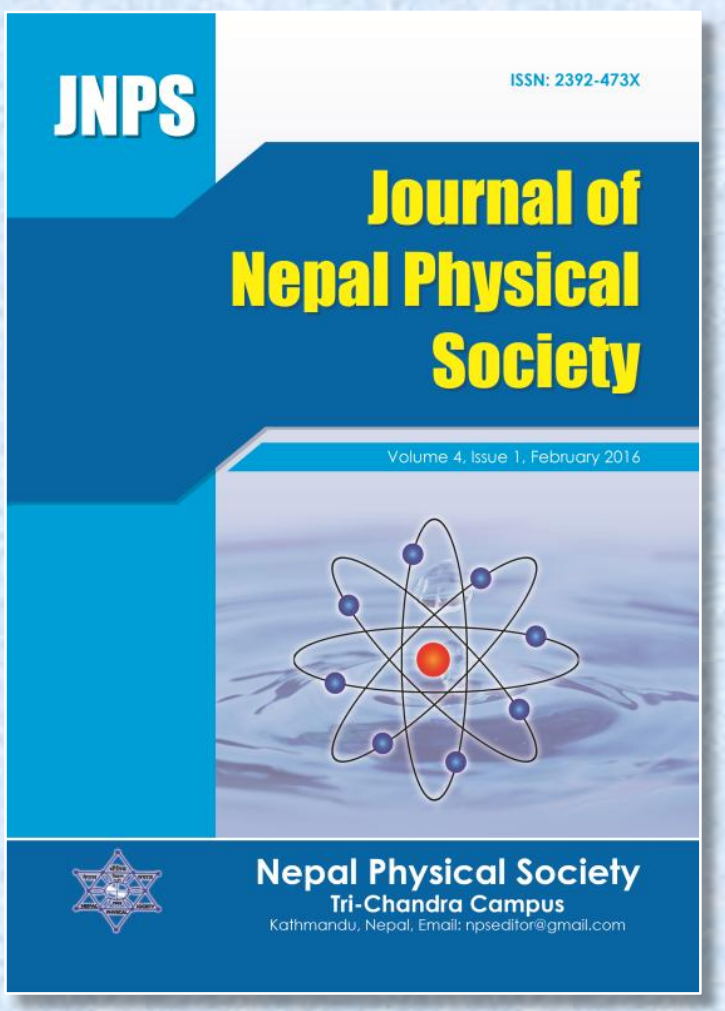

Published by:

Nepal Physical Society

P.O. Box : 2934

Tri-Chandra Campus

Kathmandu, Nepal

Email: npseditor@gmail.com 


\title{
Preparation and Characterization of Zinc Oxide Based Photoanode for Dye-sensitized Solar Cell using Delonix Regia Natural Dye Extract
}

\author{
Leela Pradhan Joshi ${ }^{1 *}$, Yamuna Poudel ${ }^{1,}$ Mim Lal Nakarmi ${ }^{2}$, \\ Pradip Raj Niraula ${ }^{2}$, Shankar Prasad Shrestha ${ }^{3}$ \\ ${ }^{1}$ Department of Physics, Amrit Science Campus, Tribhuvan University, Kathmandu, Nepal \\ ${ }^{2}$ Department of Physics, The Graduate Center and Brooklyn College of the City University of New York \\ ${ }^{3}$ Department of Physics, Patan Multiple Campus, Tribhuvan University, Lalitpur, Nepal \\ *Corresponding Email: leela.pradhan@gmail.com
}

\begin{abstract}
As of late, research on the fabrication of natural dye-sensitized solar cells has been growing tremendously, largely due to its low cost and environmentally friendly nature. We have fabricated Zinc Oxide $(\mathrm{ZnO})$ based Dye-sensitized Solar Cell (DSSC) using Delonix Regia, locally known as the Gulmohar flower natural dye extract. Zinc Oxide nanostructure films were allowed to grow on Fluorine-doped Tin Oxide (FTO) substrates via hydrothermal process. The seed layer for this was prepared by the spin coating method. The $\mathrm{ZnO}$ film's structure, topology, and optical properties were then studied using X-ray Diffraction (XRD), an Atomic Force Microscope (AFM) and an Ultraviolet Visible (UV-Vis) Spectrophotometer respectively. The $\mathrm{X}$-ray results showed the hexagonal system structure of $\mathrm{ZnO}$ oriented along (101) planes. The effect of ethylene glycol on the structural property of $\mathrm{ZnO}$ film was also studied. The current voltage curve of DSSC showed the open circuit voltage and short circuit current of $360 \mathrm{mV}$ and $80 \mu \mathrm{A}$ respectively.
\end{abstract}

Keywords: Natural Dye-sensitized Solar Cell, Transmittance, Band Gap, ZnO film.

\section{INTRODUCTION}

Solar energy is unquestionably the most abundant form of energy found on the earth. The rising energy demand of our society could be sufficiently fulfilled through the development of solar cells which utilize this solar energy (Baxter \& Aydil, 2005). Recently, solar photovoltaic technology has begun to attract attention as a potential alternative energy source for the future. Dye-sensitized Solar Cell (DSSC) invented by Brian O'Regan and Michael Grätzel in 1991 showed a noteworthy efficiency which was fabricated with a monolayer of Ruthenium dye adsorbed into the wide band mesoporous semiconducting layer of Titanium dioxide $\left(\mathrm{TiO}_{2}\right)(\mathrm{O}$ 'Regan \& Grätzel, 1991; Grätzel, 2003). In DSSC, the electrons which are created at LUMO level of dye by absorption of photons from solar energy transfer to conduction band of wide band gap of $\mathrm{TiO}_{2}$ and finally to the FTO electrode (Grätzel, 2004). Another similar semiconducting material which is extensively studying to utilize in the preparation of DSSC is Zinc Oxide because of its properties such as nearly equal to band gap as that of $\mathrm{TiO}_{2}$, great transparency and easy to fabricate with different nanostructured films (Baxter \& Aydil, 2006). Recently, ZnO with various nanostructures: nanowires, nanorods, nanoflowers, or nanosheets have garnered attention due to excellent optical, electrical and structural properties (Kanmani et al., 2012; Plank et al., 2009). The $\mathrm{ZnO}$ based DSSC has been widely investigated as a third generation solar cells because of its potential commercialization, low cost and simple construction (Suh et al., 2007). It has higher electron mobility than $\mathrm{TiO}_{2}$ and lower recombination probability. $\mathrm{ZnO}$ based solar cells can be fabricated at low cost using environmentally friendly materials: $\mathrm{ZnO}$ and natural dye extraction from locally available fruits and flowers (Chang \& Lo, 2010; Bhogaita et al., 2016; Gomez-Ortiz et al., 2010). However, $\mathrm{ZnO}$ based DSSCs with natural dyes show lower efficiency, intensive studies have been conducted to lower the cost of DSSCs to maintain the same efficiency of silicon-based solar cells. The overall effectiveness of DSSCs depends on several factors such as adsorption of dye into the $\mathrm{ZnO}$ nanostructures and absorption spectrum of dye (Hao et al., 2006; Hemmatzadeh \& Mohammadi, 2013). The most commonly used synthetic dye in DSSC assembly is N719 (Grätzel, 2003; Grätzel, 2004). This dye shows intense absorption in the visible range and highly efficient metal-to-ligand 
charge transfer. However, natural dye extracted from different parts of plants such as fruits, flowers and barks etc. have been used in fabricating inexpensive dye-sensitized solar cells. The natural dye extracts from colored flowers and fruits generally consist of anthocyanin, xanthonens pigments which are responsible to create sensitization of semiconductor in DSSC (Bhogiata et al., 2016; Hee-Je, et al., 2013). In this report, we have presented preparation of $\mathrm{ZnO}$ films using hydrothermal process (Zhang et al., 2012). The materials were characterized by $\mathrm{X}$-ray diffraction and atomic force microscope. The effect of addition of ethylene glycol into the parent solution on the structural property of $\mathrm{ZnO}$ film has been also studied. Finally, a current voltage (I-V) characteristic of the DSSC assembled with Delonix Regia locally known as Gulmohar flower dye extract are presented here.

\section{EXPERIMENTAL}

Firstly, we prepared Zinc Oxide seed layers using a spin coating method which was then used to grow a nanostructure layer of $\mathrm{ZnO}$ via hydrothermal process as described in our previous paper (Joshi et al., 2015). We prepared the precursor solutions of $0.4 \mathrm{M}$ of zinc acetate in ethanol with diethanolamine (DEA) and 1\% Ethylene Glycol (EG) separately. The purpose of mixing EG into the solution was to increase the porosity of $\mathrm{ZnO}$ film (Lee et al., 2013). After spin coating the solutions, samples were finally annealed in air at $350 \pm 5{ }^{\circ} \mathrm{C}$ for 30 minutes to convert zinc acetate into $\mathrm{ZnO}$. The $0.2 \mathrm{M}$ growth solution of the mixture of zinc nitrate hexahydrated $\left(\mathrm{Zn} \quad\left(\mathrm{NO}_{3}\right)_{2} \cdot 6 \mathrm{H}_{2} \mathrm{O}\right)$ and hexamethylenetetramine (HMTA, $\mathrm{C}_{6} \mathrm{H}_{12} \mathrm{~N}_{4}$ ) in distilled water was prepared for hydrothermal process. The $\mathrm{ZnO}$ seeded substrates were then immersed vertically into these growth solutions for 2 hours at the constant temperature of $90 \pm 5{ }^{\circ} \mathrm{C}$. Subsequently, the substrates were rinsed with distilled water and annealed in air at $350 \pm 5{ }^{\circ} \mathrm{C}$ for 30 minutes. The samples prepared from solution without EG and with EG into the parent solution are named as $A_{1}$ and $A_{2}$ respectively. X-ray diffraction experiment was performed to investigate the structure of as-grown $\mathrm{ZnO}$ film. The surface morphology study of as-prepared sample $A_{1}$ was performed using Digital Instrument Atomic Force Microscope (AFM) available at Brooklyn College of the City University of New York (CUNY). Optical analysis of sample, $\mathrm{A}_{1}$ was done using an ultraviolet-visible spectrophotometer USB 2000,
Ocean Optics, Singapore. The structural study of samples $A_{1}$ and $A_{2}$ was investigated using $\mathrm{X}$-ray diffraction technique employing $\mathrm{CuK}_{\alpha}, \lambda=1.54184$ $\AA$. The power used in the experiment was of $30 \mathrm{kV}$ with a current of $10 \mathrm{~mA}$, and the $2 \theta$ scan angle was ranging from $20^{\circ}$ to $80^{\circ}$ with scanning rate of 0.33 degree per second. We used the natural dye extract of Delonix Regia to sensitize the $\mathrm{ZnO}$ electrodes. 1 gm of dry grinded powder of Delonix Regia flower dissolved in $60 \mathrm{ml}$ of ethanol at room temperature of $25{ }^{\circ} \mathrm{C}$ for $12 \mathrm{hrs}$ for dye extraction. The colored solution was then filtered using a clean strainer. The above prepared samples of $\mathrm{ZnO}$ samples, A1 and A2 were dipped into this dye solution at $60 \pm 5$ ${ }^{\circ} \mathrm{C}$ for 6 hours for dye loading to take place. The absorbance of $\mathrm{ZnO}$ film was recorded using the Spectrophotometer. A graphite coated FTO and liquid potassium iodide and iodine electrolyte was used to assemble the dye-sensitized solar cell (Grätzel, 2004). To test the performance of assembled dye-sensitized solar cell, current voltage characteristic curve were drawn in dark light and sunlight. In our experiment the current and voltage measurements were taken using Fluke 179 digital multimeters.

\section{RESULTS AND DISCUSSION}

Figures 1(a) and 1(b) show the X-ray diffraction pattern of samples $A_{1}$ and $A_{2}$ grown on FTO substrates respectively. The Figure 1a shows a sharp peak at $2 \theta=36.0375^{\circ}$ which corresponds to $\mathrm{d}=2.4923 \AA$ orienting along (101) plane of $\mathrm{ZnO}$ with reference to JCPDS PDF\# 36-1451 (Gümüs et al., 2006; Xu et al., 2006).

The peaks observed at $2 \theta=28.1934^{0}(\mathrm{~d}=3.165 \AA$ Á) and $2 \theta=37.8619^{\circ}(\mathrm{d}=2.376 \AA)$ shown in table 1 correspond to (110) and (200) planes of FTO with reference to JCPDS file number 41-1445 (Banerjee et al., 2003). Other two small peaks observed at $2 \theta$ $=49.1056^{\circ}$ and $2 \theta=56.232^{\circ}$ corresponds to (102) and (110) planes of $\mathrm{ZnO}$ respectively. Another low intensity peak observed at $2 \theta=64.3428^{\circ}(\mathrm{d}=1.447$ $\AA$ ) corresponds to orientation of (112) of FTO. Similar set of observations has been observed in $\mathrm{A}_{2}$ sample but with a slight shift in d values. All the observed d-spacing, FWHM and JCPDS d-spacing values corresponding to XRD pattern of Figure 1(a) and Figure 1(b) are shown in the table 1. The presence of these peaks demonstrates that the prepared $\mathrm{ZnO}$ film is of polycrystalline type. The observed results show that only slight changes in peak position, intensity and widths for the presence of ethylene glycol in sample $A_{2}$. This shows that 
presence of EG in the parent solution does not lead to any structural change. The crystallite size, D, of $\mathrm{ZnO}$ film was estimated using Debye Scherrer's equation $D=\frac{0.9 \lambda}{\beta \cos \theta}, \lambda$ is the wavelength of the

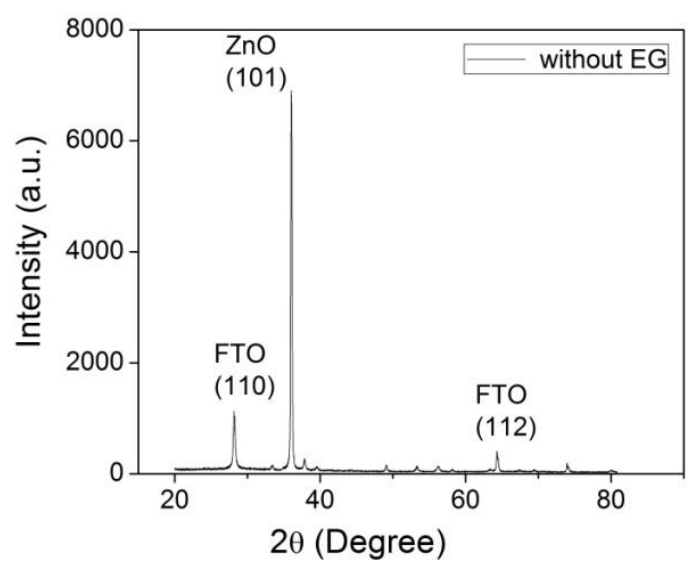

(a)
$\mathrm{X}$-ray used, $\beta$ is the broadening of peak at half the maximum intensity or FWHM and $\theta$ is the Bragg's angle. The calculated value of $\mathrm{D}$ corresponding to sharp $\mathrm{ZnO}$ peak (101) was found to be of about $31 \mathrm{~nm}$.

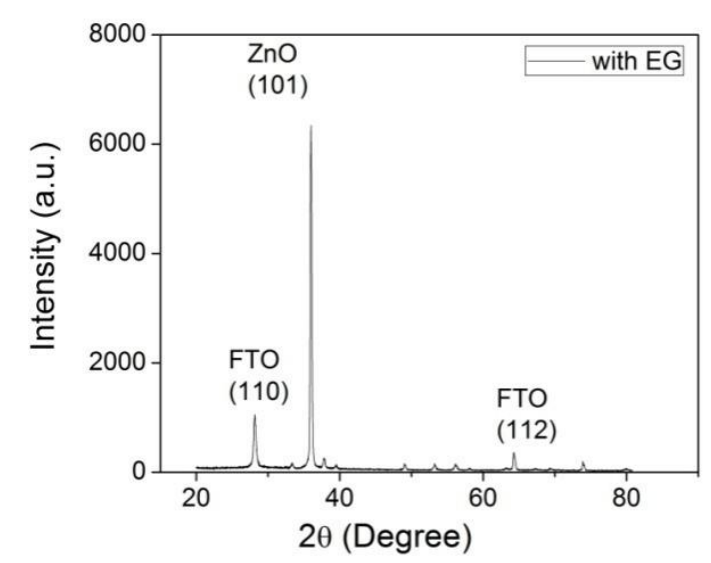

(b)

Fig. 1. XRD pattern of ZnO film (a) without and (b) with ethylene glycol into the parent solution of seed layer

Table 1. Peak position, width of peaks, d-spacings, (h $\mathrm{k}$ l) values and phase of FTO and ZnO films

\begin{tabular}{|c|c|c|c|c|c|c|c|}
\hline Sample & $\begin{array}{l}\text { Peak position } \\
(2 \theta)\end{array}$ & $\begin{array}{l}\text { FWHM } \\
\text { (Degree) }\end{array}$ & $\begin{array}{l}\text { Observed } \\
\text { d- value }(\AA)\end{array}$ & $\begin{array}{l}\text { d-value } \\
\text { from JCPDS }\end{array}$ & (h k l) & Phase & $\begin{array}{l}\text { JCPDS } \\
\text { card no. }\end{array}$ \\
\hline \multirow{7}{*}{$\mathrm{A}_{1}$} & 28.1934 & 0.323 & 3.165 & 3.347 & (110) & FTO & 41-1445 \\
\hline & 36.0375 & 0.218 & 2.4923 & 2.4759 & $\left(\begin{array}{lll}1 & 0 & 1\end{array}\right)$ & $\mathrm{ZnO}$ & $36-1451$ \\
\hline & 37.8619 & 0.264 & 2.376 & 2.369 & $\left(\begin{array}{lll}2 & 0 & 0\end{array}\right)$ & FTO & 41-1445 \\
\hline & 49.1056 & 0.262 & 1.8552 & 1.9110 & (102) & $\mathrm{ZnO}$ & $36-1451$ \\
\hline & 53.3159 & 0.264 & 1.718 & & & & \\
\hline & 56.2320 & 0.409 & 1.6358 & 1.6247 & (11 0) & $\mathrm{ZnO}$ & $36-1451$ \\
\hline & 64.3428 & 0.307 & 1.447 & 1.4392 & (112) & FTO & $41-1445$ \\
\hline \multirow{8}{*}{$\mathrm{A}_{2}$} & & & & & & & \\
\hline & 28.1682 & 0.366 & 3.168 & 3.347 & (110) & FTO & $41-1445$ \\
\hline & 36.0039 & 0.266 & 2.4944 & 2.4759 & (101) & $\mathrm{ZnO}$ & $36-1451$ \\
\hline & 37.8390 & 0.305 & 2.3776 & 2.369 & $\left(\begin{array}{lll}2 & 0 & 0\end{array}\right)$ & FTO & 41-1445 \\
\hline & 49.0796 & 0.294 & 1.856 & 1.9110 & (102) & $\mathrm{ZnO}$ & $36-1451$ \\
\hline & 53.2430 & 0.275 & 1.72 & & & & \\
\hline & 56.1716 & 0.395 & 1.637 & 1.6200 & (110) & $\mathrm{ZnO}$ & $36-1451$ \\
\hline & 64.3143 & 0.314 & 1.448 & 1.4392 & (112) & FTO & $41-1445$ \\
\hline
\end{tabular}

Figure 2a shows the transmittance of $\mathrm{ZnO}$ film (sample $\mathrm{A}_{1}$ ) grown on FTO substrates by hydrothermal method. The transmittance curve was captured in the wavelength range of $300-1000 \mathrm{~nm}$. 
From this transmittance curve we can plot the variation of $(\alpha h v)^{2}$ with $h v$ to calculate the band gap of $\mathrm{ZnO}$ film, by using the equation 1below (Shrestha et al., 2010).

$$
(\alpha h v)^{2}=A\left(h v-E_{g}\right)
$$

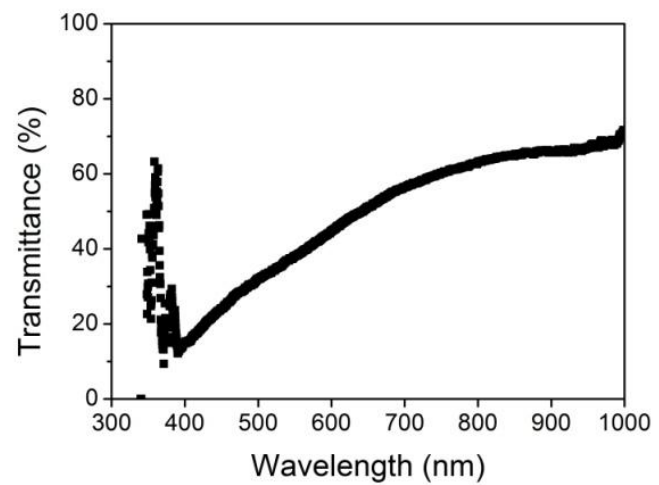

(a) where $\mathrm{A}$ is an energy independent constant, $\mathrm{h}$ is the Planck constant, hv is the energy of the incident photons and $E_{g}$ is the optical band gap. Corresponding $(\alpha h v)^{2}$ versus hv plot was shown in the figure 2 (b). By extrapolating the linear portion of this plot on $h v$ axis we estimated the direct optical band gap energy of $\mathrm{ZnO}$ around $2.87 \mathrm{eV}$.

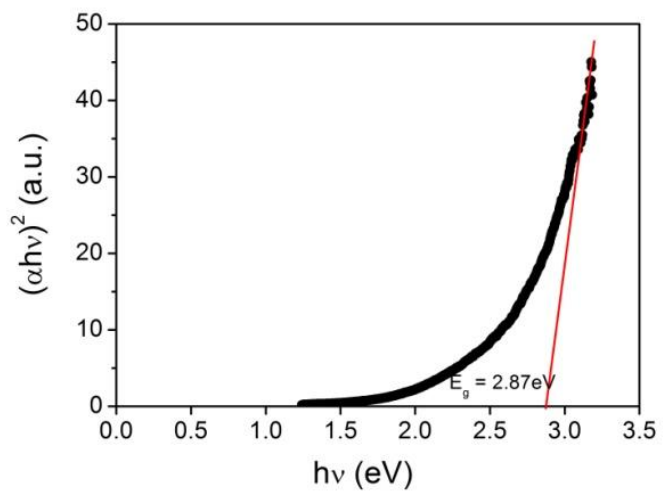

(b)

Fig. 2. (a) Transmittance of $\mathrm{ZnO}$ film $\left(A_{1}\right)\left(\right.$ b) the corresponding graph of $(\alpha h v)^{2}$ versus $h v$.

Figure 3 shows AFM images of $\mathrm{ZnO}$ film (sample $\mathrm{A}_{1}$ ) prepared by hydrothermal process at $90 \pm 5^{\circ} \mathrm{C}$. Figure 3 a shows the top view of the AFM image of $\mathrm{ZnO}$ film $\mathrm{A}_{1}$ and Figure $3 \mathrm{~b}$ shows $3 \mathrm{D}$ view of the image. The images were taken in tapping mode. The image clearly shows grain like surface morphology. The root mean square value of the surface roughness is around $47 \mathrm{~nm}$.
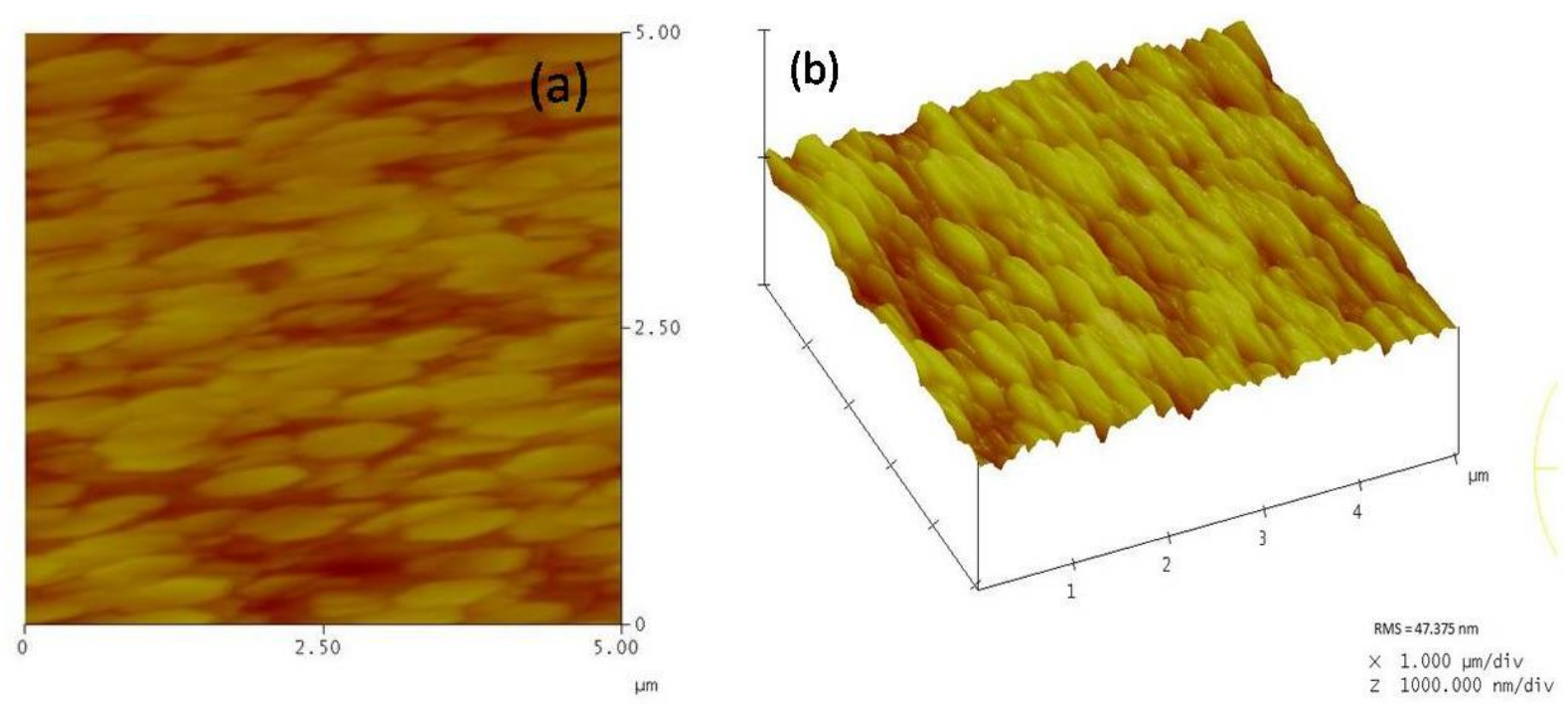

Fig. 3. (a) Top view of the Atomic Force Microscope image and (b) 3D view of ZnO film (sample $A_{1}$ ) grown on FTO substrate.

We used natural dye extract of Delonix Regia to create sensitization on $\mathrm{ZnO}$ photoanodes prepared by hydrothermal route on FTO substrates in order to assemble dye-sensitized solar cell. The absorption spectrum of $\mathrm{ZnO}$ electrode after loading Delonix Regia dye extract is shown in Figure 4a. 


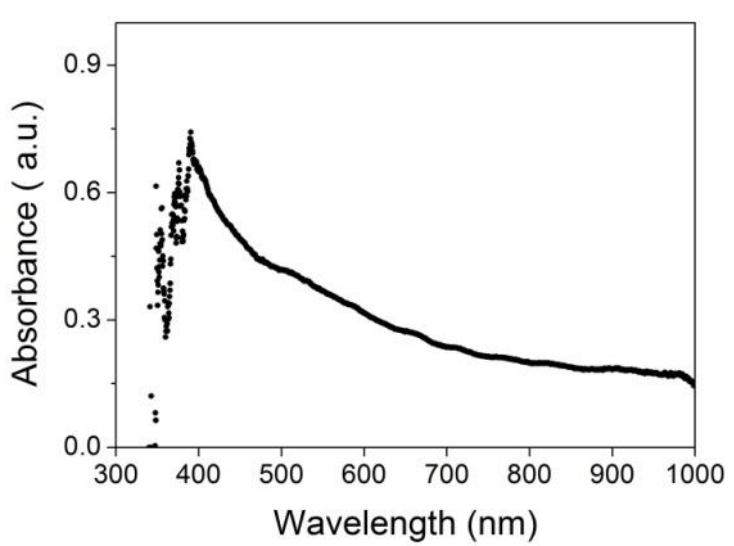

(a)

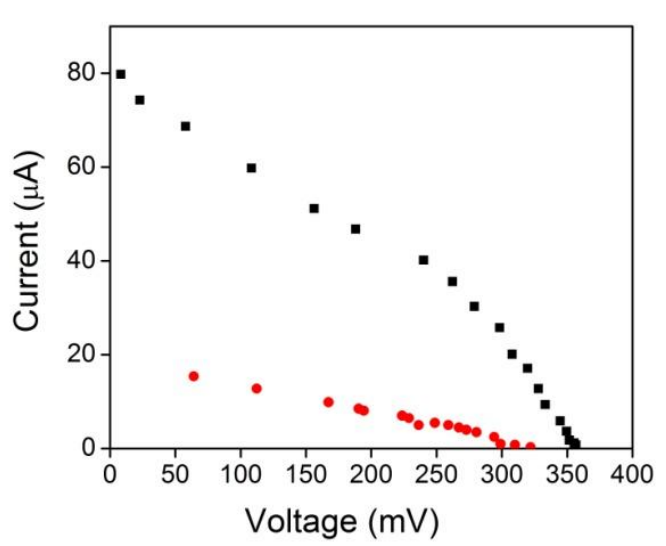

(b)

Fig. 4. (a) Absorbance as a function of wavelength of Delonix Regia loaded into ZnO photoanode (b) the current voltage characteristic curve of DSSC using Delonix Regia dye extract. The black filled square and red filled circle symbols here represent measurements taken in presence of sunlight and dark light respectively.

The absorption peak was observed at wavelength of $389 \mathrm{~nm}$ and the absorption extends up to about $600 \mathrm{~nm}$ and beyond this the absorption is low. This shows the quite enough wide absorbance in the visible region of selected dye for DSSC. Then, above prepared $\mathrm{ZnO}$ electrode was dipped into the dye solution for 6 hours at $60 \pm 5^{\circ} \mathrm{C}$ for dye loading. The current voltage measurements of assembled DSSC were performed in presence of sunlight (black squares) and in dark light (absence of sunlight represented by red circles) using two Fluke 179 digital millimeters were shown in Figure 4b. This figure clearly shows that as the intensity of incident light was increased from dark (absence of sunlight) to high intensity (presence of sunlight), I$\mathrm{V}$ curve shifted up significantly which signifies the power generation from assembled DSSC. The results show that maximum open circuit voltage and short circuit current were of $360 \mathrm{mV}$ and 80 microampere respectively.

\section{CONCLUSIONS}

$\mathrm{ZnO}$ thin films were grown on conducting FTO substrates using a two step; spin coating and hydrothermal process. The XRD analysis shows $\mathrm{ZnO}$ films were of hexagonal system structure with (101) oriented planes. The average crystallite size of $\mathrm{ZnO}$ was found to be about $31 \mathrm{~nm}$. Presence of EG into the parent solution shows no significant change in XRD pattern of $\mathrm{ZnO}$ film. AFM image of prepared $\mathrm{ZnO}$ film shows the grain like surface morphology with roughness of $47 \mathrm{~nm}$. The optical band gap of $\mathrm{ZnO}$ film from optical analysis is found to be $2.87 \mathrm{eV}$. Current voltage measurement on fabricated dye-sensitized solar cell using Delonix Regia dye extract shows the open circuit voltage of 360 millivolts and short circuit current of 80 microamperes respectively.

\section{ACKNOWLEDGMENT}

The authors would like to thank Nepal Academy of Science and Technology (NAST), Khumaltar, Kathmandu, Nepal for providing partial financial support to conduct this research work.

\section{REFERENCES}

Baxter, J. B., \& Aydil, E. S. (2005). Nanowirebased dye-sensitized solar cells. Applied Physics Letters, 86, 053114(1)- 053114(3).

Baxter, J. B., \& Aydil, E. S. (2006). Dye-sensitized solar cells based on semiconductor morphologies with $\mathrm{ZnO}$ nanowires. Solar Energy Materials \& Solar Cells, 90, 607622.

Banerjee, A. N.; Kundoo, S.; Saha, P., \& Chattopadhyay, K. K. (2003). Synthesis and characterization of nano-crystalline FluorineDoped Tin Oxide thin films by Sol-Gel method. Journal of Sol-Gel Science and Technology, 28, 105-110.

Bhogaita, M.; Shukla, A. D., \& Nalini, R. P. (2016). Recent advances in hybrid solar cells based on natural dye extracts from Indian 
plant pigment as sensitizers. Solar Energy, 137, 212-224.

Chang, H., \& Lo, Y. J. (2010). Pomegranate leaves and mulberry fruit as natural sensitizers for dye-sensitized solar cells. Solar Energy 84, 1833-1837.

Gomez-Ortiz, N. M.; Vazquez-Maldonado, I. A.; Perez-Espadas, A. R., \& Mena-Rejon G. J. (2010). Dye-sensitized solar cells with natural dyes extracted from achiote seeds. Solar Energy Materials \& Solar Cells, 94, 40-44.

Grätzel, M. (2003). Dye sensitized solar cells. Journal of Photochemistry and Photobiology C: Photochemistry Reviews, 4, 145-153.

Grätzel, M. (2004). Convsersion of sunlight to electric power by nanocrystalline dyesensitized solar cells. Journal of Photochemistry and Photobiology A: Chemistry, 164, 3-14.

Gümüs, C.; Ozkendir, H.; Kavak, H., \& Ufuktepe, Y. (2006). Structural and optical properties of zinc oside thin films prepared by spray pyrolysis method. Journal of optoeletronics and advanced materials , 8, 299-303.

Hao, S.; Wu, J.; Huang, Y., \& Lin, J. (2006). Natural dyes as photo sensitizers for dyesensitized solar cell. Solar Energy 80, 209214.

Hemmatzadeh, R., \& Mohammadi, A. (2013). Improving optical absorptive of natural dyes for fabrication of efficient dye-sensitized solar cells. Journal of Theoretical and Applied Physics, 7, 57-63.

Hee-Je, K. H. J.; Bin, Y.T.; Karthick, S. N.; Hemalatha, K. V.; Justin, R. C.; Venkatesan, S.; Park, S., \& Vijayakumar, G. (2013). Natural dye extracted from Rhododendron species flowers as a photosensitizer in dye sensitized solar Cell, Int. J. Electrochem. Sci., 8, $6734-6743$.

Joshi, L. P.; Subedi, K. P.; Dangol, L.; Shrestha, P., \& Shrestha, S. P. (2015). Preparation and characterization of zinc oxide nanosheets for dye-sensitized solar cell using vitis vinifera dye extraction. Journal of Electrical and Electronics Engineering, 2, 1-15.
Kanmani, S. S.; Ramachandran, K., \& Umapathy, S. (2012). Eosin Yellowish dye-sensitized $\mathrm{ZnO}$ nanostructure Based solar cells employing solid PEO redox couple electrolyte. International Journal of Photoenergy, 2012, Article ID 267824, 1-8.

Lee, P. Y.; Chang, S. P., \& Chang, S.-J. (2013). Synthesis and optical properties of $\mathrm{ZnO}$ thin films prepared by SILAR method with ethylene glycol, 1, 93-103.

O'Regan, B., \& Gratzel, M. (1991). A low-cost high-efficiency solar cell based on dyesensitized colloidal $\mathrm{TiO}_{2}$ films. Nature, 335, 737-740.

Plank, N. O. V.; Howard, I.; Rao, A.; Wilson, M. W. B.; Ducati, C.; Mane, R. S. et. al (2009). Efficient $\mathrm{ZnO}$ nanowire solid-state dyesensitized solar cells using organic dyes and core-shell nanostructures. Journal of Physical Chemistry C, 113, 18515-18522.

Suh, D. I.; Lee, S. Y.; Kim, T. H.; Chun, J. M.; Suh, E. K.; Yang, O. B, \& Lee, S. K. (2007). The fabrication and characterization of dyesensitized solar cells with a branched structures of $\mathrm{ZnO}$ nanowires. Chemical Physics Letters, 442, 348-353.

Shrestha, S. P.; Ghimire, R.; Nakarmi, J. J.; Kim, Y. S.; Shrestha, S.; Park, C. Y., \& Boo, J. H. (2010). Properties of $\mathrm{ZnO}: \mathrm{Al}$ films prepared by spin coating of aged precursor solution. Bull Korean Chemistry Society, 31, 1-4.

Xu, Z. Q.; Deng, H.; Guo, Y.; Li, Q. H., \& Li, Y. R. (2006). Characteristics of Al-doped c-axis orientation $\mathrm{ZnO}$ thin films prepared by the sol-gel method. Materials Research Bulletin, 41, 354-358.

Zhang, Y.; Ram, M. K.; Stefanakos, E. K., \& Goswami, D. Y. (2012). Synthesis, characterization, and applications of $\mathrm{ZnO}$ nanowires. Journal of Nanomaterials, Article ID624450, 1-22. 